\title{
Stressors in attempted suicide by poisoning: a sex comparison
}

\author{
Estressores na tentativa de suicídio por envenenamento: \\ uma comparação entre os sexos
}

Maria Cláudia da Cruz Pires, ${ }^{1}$ Maria Cristina Falcão Raposo, ${ }^{2}$ Marcela Pires, ${ }^{1}$
Everton Botelho Sougey ${ }^{3}$ Othon Coelho Bastos Filho ${ }^{4}$

\begin{abstract}
Introduction: To identify stressors in attempted suicide by poisoning and to analyze differences between men and women.

Method: This quantitative, comparative, cross-sectional study evaluated 110 patients aged between 14 and 78 years. The following instruments were used: standardized Mini International Neuropsychiatric Interview (MINI) version 5.0.0 and an interview form specifically designed for the study.

Results: $70 \%$ of the suicide attempters were female; mean age was 28.1 years; $98.2 \%$ presented at least one psychiatric disorder. Among the stressors assessed, significant differences were observed between men and women for: not having a spouse, $72.7 \%$ among men and $54.5 \%$ among women; attempted suicide planning, $66.7 \%$ among men and $46.8 \%$ among women; being under the influence of alcohol during the attempted suicide, $51.5 \%$ among men and $26.0 \%$ among women; harmful use of alcohol, $42.4 \%$ in men and $22.1 \%$ in women; sexual abuse, $22.1 \%$ in women and $6.1 \%$ in men.

Conclusions: Women presented a three times higher number of attempted suicides by poisoning. The identification of stressors with significant differences between sexes in the high-risk population here described can help define and organize strategies aimed at suicide prevention. Similar studies should be conducted in the general population.
\end{abstract}

Keywords: Attempted suicide, poisoning, sex, stressors.

\begin{abstract}
Resumo
Introdução: Identificar estressores na tentativa de suicídio por envenenamento e analisar diferenças entre homens e mulheres. Método: Estudo quantitativo, transversal e comparativo que avaliou 110 pacientes, com idades entre 14 e 78 anos. Os instrumentos de avaliação utilizados foram: entrevista padronizada Mini International Neuropsychiatric Interview (MINI), versão 5.0.0, e formulário de entrevista desenvolvido especificamente para o estudo.

Resultados: $70 \%$ dos pacientes eram mulheres; a idade média foi de 28,1 anos; $98,2 \%$ apresentavam pelo menos um transtorno psiquiátrico. Dentre os estressores avaliados, foram observadas diferenças significativas entre os sexos para: ausência de convívio conjugal, $72,7 \%$ entre homens e $54,5 \%$ entre mulheres; planejamento da tentativa de suicídio por envenenamento, $66,7 \%$ nos homens e $46,8 \%$ nas mulheres; estar sob o efeito de álcool durante a tentativa de suicídio por envenenamento, $51,5 \%$ entre os homens e $26,0 \%$ entre as mulheres; uso nocivo de bebidas alcoólicas, $42,4 \%$ dos homens e $22,1 \%$ das mulheres; abuso sexual, $22,1 \%$ das mulheres e $6,1 \%$ dos homens.

Conclusões: As mulheres apresentaram três vezes mais tentativas de suicídio por envenenamento do que os homens. A identificação de estressores com diferença significativa entre os sexos na população de risco aqui estudada oferece subsídios para a definição e prospecção de estratégias específicas para a prevenção do suicídio. Outros estudos similares na população geral devem ser realizados. Descritores: Tentativa de suicídio, envenenamento, sexo, estressores.
\end{abstract}

\footnotetext{
${ }^{1}$ Doutoranda, Programa de Pós-Graduação em Neuropsiquiatria e Ciências do Comportamento, Universidade Federal de Pernambuco (UFPE), Recife, PE, Brazil. ${ }^{2}$ Professora, Departamento de Estatística, UFPE. ${ }^{3}$ Coordenador, Programa de Pós-Graduação em Neuropsiquiatria e Ciências do Comportamento, UFPE. ${ }^{4}$ Professor titular, Psiquiatria, UFPE e Universidade de Pernambuco (UPE), Recife, PE, Brazil.

Submitted May 17 2011, accepted for publication Sep 01 2011. No conflicts of interest declared concerning the publication of this article.

Suggested citation: Pires MC, Raposo MC, Pires M, Sougey EB, Bastos Filho OC. Stressors and attempted suicide by poisoning: a sex comparison. Trends Psychiatry Psychother. 2012;34(1):25-30.
} 


\section{Introduction}

Suicidal behaviors have been the subject of studies from a wide range of scientific and literary fields. The topic is broad and controversial, and has produced a great diversity of opinions. The present article focuses on attempted suicide as defined by the World Health Organization (WHO), i.e., intentional acts of self-harm that do not result in death. ${ }^{1}$

The rates of suicide and attempted suicide are underestimated, ${ }^{2}$ and they are considered a worldwide public health problem. ${ }^{3}$ Unfortunately, over only one year (2009), the number of cases of self-poisoning treated at a public hospital in the city of Recife, northeastern Brazil, reached a mean of three new patients/day (age 14 years and older) requiring medical assistance for this specific cause. ${ }^{4}$

Identification of the most frequent stressors present in each sex in a sample selected from a population at risk for suicide attempt would provide a realistic and useful contribution taking into consideration the scarcity of financial resources available for use in public health policies aiming at more effective preventive interventions.

Although there are not official data on the rates of attempted suicide, some studies have estimated that each completed suicide may be preceded by up to 40 suicide attempts. ${ }^{5}$ Thirty to $50 \%$ of completed suicides have a history of previous suicide attempts, with a 100-times higher risk of suicide for subjects who attempted suicide in the previous year when compared with the general population not presenting such a history. ${ }^{2}$ Moreover, among previous suicide attempters, the chance of recurrence over 1 year after the attempt may range from 15 to $25 \%$, whereas $10 \%$ will complete suicide over the subsequent 10 years. ${ }^{6}$

Stressors such as arguments with close contacts, breaking up a relationship, unemployment, ${ }^{7}$ death of family members, legal or work problems, in addition to other factors, some of which remain to be known, may combine with other risk conditions, especially common mental disorders affecting the attempters themselves or their first-degree relatives, and may provoke an increase in the chance of completing or attempting suicide. ${ }^{8}$ Therefore, experiencing neglect or loss could be considered a triggering or facilitating factor of attempted suicide, regardless of sex..$^{9,10}$

Self-poisoning, especially with household chemicals, is among the most frequent methods of attempted suicide, as shown by Sougey et al. ${ }^{11}$ Those authors have described that the methods of suicide vary according to cultural factors, ease of access to lethal agents, and the intentionality of the act. ${ }^{11}$ Even though underreported, self-poisoning by prescription drugs and pesticides are the leading causes of intoxications, according to data collected by the Brazilian National System of Toxic and Pharmacological Information (Sistema Nacional de Informações Tóxico-Farmacológicas, SINITOX, www. fiocruz.br/sinitox). ${ }^{12}$

The objective of this study was to identify stressors associated with attempted suicide by poisoning and to analyze differences according to sex.

\section{Method}

This study was approved by the Research Ethics Committees of Hospital da Restauração and Universidade Federal de Pernambuco, both in Recife, northeastern Brazil. The study had a descriptive, quantitative, analytical, cross-sectional cohort design, and was conducted with patients who had attempted suicide by poisoning.

The hospital where the study was carried out is the largest public hospital in the state of Pernambuco, and since 2005 it works together with the Toxicological Treatment Center (Centro de Atendimento Toxicológico, CEATOX), affiliated with the Brazilian Network of Toxicological Information Centers (Rede Nacional dos Centros de Informações Toxicológicas, RENACIAT). Cases treated at the CEATOX are entered into a database that is also accessed by SINITOX and by the Brazilian Health Surveillance Notification System (Sistema de Notificações em Vigilância Sanitária, NOTIVISA), of the National Health Surveillance Agency (Agência Nacional de Vigilância Sanitária, ANVISA), which help identify intoxication cases. ${ }^{12}$

The study population originated from cases treated at Hospital da Restauração between January and August 2009. Among the 947 patients who had attempted suicide by poisoning and survived, 110 male and female patients were randomly selected for assessment.

The following instruments were used to assess patients: 1) The Mini International Neuropsychiatric Interview (MINI) was used to diagnose psychiatric conditions; and 2) an interview form specifically designed for the present study, filled in during an interview, was used to collect data on sociodemographic characteristics, clinical history, personal and family information, and some life curve data (from childhood to elderly).

The data collected were used to create a database, analyzed using the Statistical Package for the Social Sciences (SPSS), version 13.0. The outcomes of interest were univariate and bivariate distributions expressed as absolute and percentage frequencies. Descriptive data were calculated as mean and standard deviation. Pearson's chi-square test for independence was used to analyze associations according to sex, at a significance level of $5 \%$. In some cases, significance levels below $10 \%$ were also considered. 


\section{Results}

The main demographic characteristics of the sample are described in Table 1 . Most patients were women (70\%). Age ranged from 14 to 78 years among females and from 14 to 50 years among males; mean age was 28.1 years. Among men, $72.7 \%$ did not have a spouse/ partner, compared with $54.5 \%$ of the women (statistical significant difference at $7.4 \%$ ). Financial dependence was more common among women, accounting for $62.3 \%$ of the patients, compared with $48.5 \%$ of men.

Table 2 shows the frequency of mental disorders and lifetime traumatic events, with rates as high as $93.5 \%$ for women and $84.8 \%$ for men with mental disorders in the family $(p=0.079)$. Psychiatric disorders were present in all male patients and in $97.4 \%$ of the female patients. Psychiatric comorbidities were identified in $72.7 \%$ of men and $59.7 \%$ of women. Childhood trauma was present in $64.9 \%$ of women and $57.6 \%$ of men. Childhood sexual abuse was confirmed by $22.1 \%$ of women and only $6.1 \%$ of men, at a significant difference $(p=0.042)$.

Analysis of psychiatric disorders (Table 3) revealed that depression was present in $72.7 \%$ of men and $70.1 \%$ of women. Drug abuse (except alcohol) was higher among men (18.2 vs. $7.8 \%$ ). Generalized anxiety disorder was more frequent in women (31.2 vs. 18.2\%). Harmful use of alcohol was observed in $42.4 \%$ of males and $22.1 \%$ of females, at a statistically significant difference ( $p=$ 0.030).

Some of the stressors associated with attempted suicide by poisoning are described in Table 4 . The reason given by patients to explain their act of self-harm was related to relationship/family problems in $74 \%$ of women vs. $66.7 \%$ of men. Suicide ideation was confirmed in $80.5 \%$ of women and $78.8 \%$ of men. Attempted suicide by poisoning was planned by $66.7 \%$ of men and $46.8 \%$ of women, with a statistically significant difference at $5.5 \%$. Previous suicide attempts were informed by $33.8 \%$ of women and $24.2 \%$ of men.

Table 1 - Sociodemographic variables according to sex

\begin{tabular}{|c|c|c|c|}
\hline Variables & Males & Females & p* \\
\hline Distribution according to sex ${ }^{+}$ & $33(30.0)$ & $77(70.0)$ & \\
\hline Age (years), mean \pm standard deviation & $28.1 \pm 8.4$ & $28.1 \pm 11.5$ & \\
\hline \multicolumn{4}{|l|}{ Lives with spouse/partner ${ }^{+}$} \\
\hline Yes & $9(27.3)$ & $35(45.5)$ & \\
\hline No & $24(72.7)$ & $42(54.5)$ & 0.074 \\
\hline \multicolumn{4}{|l|}{ Financially dependent $^{+}$} \\
\hline Yes & $16(48.5)$ & $48(62.3)$ & \\
\hline No & $17(51.5)$ & $29(37.7)$ & 0.29 \\
\hline
\end{tabular}

*Pearson's chi-square test for independence.

+ Data expressed as n (\%).

Table 2 - Presence of disorders and traumatic events according to sex, $\mathrm{n}$ (\%)

\begin{tabular}{|c|c|c|c|}
\hline Disorders and traumatic events & Males & Females & p* \\
\hline \multicolumn{4}{|l|}{ Mental disorder in the family } \\
\hline Yes & $28(84.8)$ & $72(93.5)$ & \\
\hline No & $2(6.1)$ & $0(0.0)$ & \\
\hline Does not know & $3(9.1)$ & $5(6.5)$ & 0.079 \\
\hline \multicolumn{4}{|l|}{ Psychiatric disorder } \\
\hline Yes & $33(100.0)$ & $75(97.4)$ & \\
\hline No & $0(0.0)$ & $2(2.6)$ & 0.35 \\
\hline \multicolumn{4}{|l|}{ Psychiatric comorbidity } \\
\hline Yes & $24(72.7)$ & $46(59.7)$ & \\
\hline No & $9(27.3)$ & $31(40.3)$ & 0.194 \\
\hline \multicolumn{4}{|l|}{ Other traumatic events (childhood) } \\
\hline Yes & $19(57.6)$ & $50(64.9)$ & \\
\hline No & $14(42.4)$ & $27(35.1)$ & 0.464 \\
\hline \multicolumn{4}{|l|}{ Sexual abuse (childhood) } \\
\hline Yes & $2(6.1)$ & $17(22.1)$ & \\
\hline No & $31(93.9)$ & $60(77.9)$ & 0.042 \\
\hline
\end{tabular}

*Pearson's chi-square test for independence. 
Table 5 shows the agents most frequently used in attempted suicide by poisoning. More men (51.5\%) than women $(26.0 \%)$ were under the influence of alcohol during the attempted suicide, at a statistically significant difference $(p=0.009)$. Psychiatric medications were used by 41.6 vs. $30.3 \%$ of women and men, respectively. The use of other prescription drugs was reported by $14.3 \%$ of women and $9.1 \%$ of men. The intake of pesticides was confirmed in $57.6 \%$ of men and $40.3 \%$ of women, with a significant difference at $9.5 \%$.

Table 3 - Psychiatric disorders according to sex, n (\%)

\begin{tabular}{|c|c|c|c|}
\hline Psychiatric disorders & Males & Females & p* \\
\hline \multicolumn{4}{|l|}{ Depressive episode } \\
\hline Yes & $24(72.7)$ & $54(70.1)$ & \\
\hline No & $9(27.3)$ & $23(29.9)$ & 0.783 \\
\hline \multicolumn{4}{|c|}{ Drug abuse (except alcohol) } \\
\hline Yes & $6(18.2)$ & $6(7.8)$ & \\
\hline No & $27(81.8)$ & $71(92.2)$ & 0.109 \\
\hline \multicolumn{4}{|c|}{ Generalized anxiety disorder } \\
\hline Yes & $6(18.2)$ & $24(31.2)$ & \\
\hline No & $27(81.8)$ & $53(68.8)$ & 0.161 \\
\hline \multicolumn{4}{|l|}{ Harmful use of alcohol } \\
\hline Yes & $14(42.4)$ & $17(22.1)$ & \\
\hline No & $19(53.6)$ & 60 (77.9) & 0.03 \\
\hline
\end{tabular}

Table 4 - Stressors associated with attempted suicide by poisoning according to sex, $\mathrm{n}(\%)$

\begin{tabular}{|c|c|c|c|}
\hline Stressors & Males & Females & p* \\
\hline \multicolumn{4}{|c|}{ Reason for self-harm (conflict/relationship/family) } \\
\hline Yes & $16(48.5)$ & $36(46.8)$ & \\
\hline No & $17(51.5)$ & $41(53.2)$ & 0.868 \\
\hline \multicolumn{4}{|c|}{ Suicide ideation } \\
\hline Yes & $26(78.8)$ & $62(80.5)$ & \\
\hline No & $7(21.2)$ & $15(19.5)$ & 0.835 \\
\hline \multicolumn{4}{|c|}{ Has planned attempted suicide by poisoning } \\
\hline Yes & $22(66.7)$ & $36(46.8)$ & \\
\hline No & $11(33.3)$ & $41(53.2)$ & 0.055 \\
\hline \multicolumn{4}{|c|}{ Previous suicide attempts } \\
\hline Yes & $8(24.2)$ & $26(33.8)$ & \\
\hline No & $25(75.8)$ & $51(66.2)$ & 0.322 \\
\hline
\end{tabular}

*Pearson's chi-square test for independence.

Table 5 - Main types of agents used during attempted suicide by poisoning according to sex, $\mathrm{n}(\%)$

\begin{tabular}{lccc}
\hline Types of agents & Males & Females & p* \\
\hline Alcohol & & & \\
$\quad$ Yes & $17(51.5)$ & $20(26.0)$ & 0.009 \\
$\quad$ No & $16(48.5)$ & $57(74.0)$ & \\
$\begin{array}{l}\text { Psychiatric medications } \\
\quad \text { Yes }\end{array}$ & $10(30.3)$ & $32(41.6)$ & 0.266 \\
$\quad$ No & $23(69.7)$ & $45(58.4)$ & $11(14.3)$ \\
Other prescription drugs & $3(9.1)$ & $66(85.7)$ & 0.454 \\
$\quad$ Yes & $29(90.6)$ & $31(40.3)$ & 0.095 \\
$\quad$ No & $19(57.6)$ & $46(59.7)$ & \\
Pesticides & $14(42.4)$ & \\
$\quad$ Yes & & \\
$\quad$ No &
\end{tabular}

*Pearson's chi-square test for independence. 


\section{Discussion}

The descriptive, sociodemographic, and other selfpoisoning-related data found in the present investigation provide grounds for concern in terms of public health, in accordance with previous studies. ${ }^{6}$ Analysis of some epidemiological characteristics of self-poisoning suicide attempters not only revealed features of the interrelationship between such characteristics and the occurrence of suicide, but also contributed to identify peculiarities of different self-destructive acts. ${ }^{13}$

Among the data found in our sample, the predominance of attempted suicide among women $(70.0 \%)$ is in accordance with findings of previous studies, such as those conducted by Regadas et al. $(67.0 \%)^{14}$ and Stefanello (68.1\%). ${ }^{10}$ In turn, Weissman et al. analyzed data from nine countries and observed higher frequencies of attempted suicide among women in all of them. ${ }^{15}$

According to Bastos, ${ }^{13}$ women present behaviors that are more specifically related with uncompleted suicide, e.g. they choose methods that are less lethal than those used by men. This could be one possible explanation behind the higher rates of attempted suicide observed among women. ${ }^{10,14-16}$

In the present study, the analysis of age vs. sex revealed age ranges from 14 to 78 years among women and from 14 to 50 years among men. Pires et al., ${ }^{17}$ in a literature review on risk factors for attempted suicide among the elderly, identified that survivors of selfharm behaviors are more frequent among women, at the 3:1 ratio at young ages; as age increases (in both sexes), rates approach the $1: 1$ ratio. We underscore the preponderance of attempted suicide among women. Notwithstanding, when analyzing age, we did not find cases of suicide attempt in men above 50 years of age; only female suicide attempters were observed in this age range.

We found a high frequency of depressive episodes in our sample, affecting $72.7 \%$ of men and $70.1 \%$ of women. This result differs from depression prevalence rates traditionally reported for males and females, according to which women are more prone to developing depression than men. ${ }^{18}$ However, it is important to remember that our patients were interviewed while seeking treatment for self-poisoning, which could explain the high occurrence of depressive complaints. We also speculate that such complaints could be the result of the "day after," without the influence of psychoactive substances, such as alcohol, which was more widely used among men, in accordance with previous reports. $3,6,9,10,13$

Having a psychiatric disorder resulting from the harmful use of drugs (except alcohol) was more frequent among men. Yoshimasu et al. ${ }^{19}$ have reported that depressed men are at a higher risk for this type of comorbidity. Generalized anxiety disorder was more frequent in women, which possibly explains the higher anxiety observed in these patients. According to Ohberg et al., ${ }^{20}$ anxiety may be underestimated or masked by the presence of affective disorders and/or by the use of alcohol, which supports our results of a higher rate of harmful use of alcohol among men.

Within the patient profile here described, the presence of self-destructive behaviors in both sexes in our sample seems to suggest that attempted suicide by poisoning could have been the result of loss of control, rather than of a true wish to die, in at least $53.2 \%$ of women and $33.3 \%$ of men, thus revealing a "cry for help." 21 In this sense, self-destructive behaviors would be the result of an unplanned but impulsive and irrational act, not having death as a final goal, which is in accordance with previous studies, such as the ones by Lecínio et al. ${ }^{18}$ and Botega et al. ${ }^{9}$ (those authors have shown that only a small portion of suicide attempters truly intended to die).

Living with a partner can be interpreted as an ambiguous condition with regard to the its influence on the decision to attempt suicide. However, more men reported to be single (no partner) at the time of the suicide attempt. Studies have suggested that suicide rates are lower among married men than among those living without a partner (single, divorced, widowed). ${ }^{22,23}$ In our sample, living without a partner was associated with a high incidence of psychiatric disorders, as already informed in other studies. ${ }^{24}$ Living with a spouse or partner per se cannot be seen as a protective factor against attempted suicide; when associated with specific situations, e.g. young age or financial dependence, having a partner may in fact trigger self-destructive acts. $^{25}$

Among the agents associated with attempted suicide by poisoning, the use of prescription drugs, especially among women, deserves mention. These data corroborate the findings of Sougey et al., who identified a higher predisposition of women for seeking treatment at healthcare facilities. ${ }^{11}$ In contrast, more men than women reported the intake of pesticides. This "preference" for pesticides among men can be explained, at least in part, by the more lethal suicide methods usually adopted by men. ${ }^{13,18}$

In the study conducted by Nordstrom et al., the risk of completing suicide after previous attempts was two to four times higher in men, especially in young age groups. ${ }^{26}$ Although women tend to have more depression than men, they do not present higher rates of attempted suicide specifically for this reason. ${ }^{18}$ Among depressed patients, men, especially younger ones, are at a greater 
risk of developing comorbidities with substance and/ or alcohol abuse, which further increases the risk of attempted suicide in this subgroup. ${ }^{20}$

In sum, when studying populations at risk, such as the one here described, some of the stressors that seem to facilitate attempted suicide include previous suicide attempts, continuous or heavy alcohol consumption, recent unemployment, little social support, financial difficulties, having at least one psychiatric disorder, and harmful use of psychoactive substances. Similar data have been reported by Murphy et al. ${ }^{8}$ and Pirkola et al. ${ }^{27}$

\section{Conclusions}

Comparing the rates of attempted suicide by poisoning among women and men, a 3:1 ratio was found. The most frequent stressors among men were the harmful use of alcohol and being under the influence of alcohol during the suicide attempt. Childhood sexual abuse was more frequent among men ( $p \leq 0.05$ ).

Identifying stressors and differences between sexes in a high-risk population provides realistic and useful information for the development of specific strategies aimed at preventing suicide. Further research is warranted to identify similar stressors in the general population.

In spite of the limitations of the present study, namely patient selection at one single clinic, a small sample size, and limited availability of data, we strongly believe that our findings can yield opportunities to improve the mental health of the population.

\section{References}

1. Organização Mundial da Saúde, Departamento de Saúde Mental, Transtornos mentais e comportamentais. Prevenção do suicídio: um manual para médicos clínicos gerais. Genebra: OMS; 2000. http://whqlibdoc.who.int/hq/2000/ WHO_MNH_MBD_00.1_por.pdf. Accessed Jul 2010.

2. Mello MF, Mello AF, Kohn, R. Epidemiologia da saúde mental no Brasil: epidemiologia das tentativas de suicídio e dos suicídios. Porto Alegre: Artmed; 2007.

3. Meleiro A, Teng CT, Wang, YP. Suicídio: estudos fundamentais: São Paulo: Segmento Farma; 2004.

4. Pires MCC. Estudo sobre tentativa de suicídio por envenenamento no Recife-PE, Brasil [dissertação]. Recife: Universidade Federal de Pernambuco; 2010.

5. Werlang BG, Botega NJ. Comportamento suicida. Porto Alegre: Artmed; 2004.

6. Botega NJ, Werlang BSG, Cais CFS, Macedo MMK. Prevenção do comportamento suicida. Psico. 2006;37:213-20.

7. Kposowa AJ. Unemployment and suicide: a cohort analysis of social factors predicting suicide in the US National Longitudinal Mortality Study. Psychol Med. 2001;31:127-38.
8. Murphy GE. Psychiatric aspects of suicidal behavior: substance abuse. In: Hawton K, van Heeringen $\mathrm{K}$, editors. The international handbook of suicide and attempted suicide. Chichester: John Ailey \& Sons; 2000. p. 135-46.

9. Botega N, Bertolote JM, Bessa MA, Hetem LA. Prevenção do suicídio. Debates. 2010;1:14-6.

10. Stefanello S. Tentativas de suicídio atendidas no Hospital das Clínicas - Unicamp: diferenças entre os sexos [dissertação]. Campinas: Universidade Estadual de Campinas; 2007.

11. Sougey EB, Carvalho TFR, De Matos MAG, Ferreira CRP. Tentativas de suicídio com medicamentos: experiência do CEATOX-PE, em 1995. Inf Psiquiatr. 1998;17(1):22-5.

12. Oga S, Camargo MMA, Batistuzzo JAO. Fundamentos de toxicologia. São Paulo: Atheneu; 2008.

13. Bastos O. Comportamentos suicidas em uma unidade psiquiátrica de hospital universitário [tese de livre-docência]. Recife: Universidade Federal de Pernambuco; 1975.

14. Regadas PR, Veras TN, Lins EB, Cavalcanti IO, Aguiar JC, Braga MDM. Tentativa de suicídio por auto-envenenamento: um estudo retrospectivo de 446 casos. Pesqui Med Fortaleza. 2000;3(1):50-3.

15. Weissman MM, Bland RC, Canino GJ, Greenwald S, Hwu HG, Joyce PR, et al. Prevalence of suicide ideation and suicide attempts in nine countries. Psychol Med. 1999;29:9-17.

16. Kuo WH, Gallo JJ, Tien AY. Incidence of suicide ideation and attempts in adults: the 13-year follow-up of a community sample in Baltimore, Maryland. Psychol Med. 2001;31:1181-91.

17. Pires MCC, Kurtinaitis LCL, Santos MSP, Passos MP, Sougey EB, Bastos Filho OC. Fatores de risco para tentativa de suicídio em idosos. Neurobiologia. 2009;72(4):21-8.

18. Licinio J, Wong M-L, orgs. Biologia da depressão. Porto Alegre: Artmed; 2007.

19. Yoshimasu K, Kiuohara C, Miyashita K. Suicidal risk factors and completed suicide: meta-analyses based on psychological autopsy studies. Environ Health Prev Med. 2008;13:243-6.

20. Ohberg A, Vuori E, Ojanpera I, Lonngvist J. Alcohol and drugs in suicides. Br J Psychiatry. 1996;169:75-80.

21. Farberow NL, Shneidman ES. The cry for help. New York: McGraw-Hill; 1961.

22. Smith JC, Mercy JA, Conn JM. Marital status and the risk of suicide. Am J Public Health. 1988;78:78-80.

23. Luoma JB, Pearson JL. Suicide and marital status in the United States, 1991-1996: is widowhood a risk factor? Am J Public Health. 2002;92:1518-22.

24. Harris EC, Barrowclough B. Suicide as an outcome for mental disorders: a meta-analysis. Br J Psychiatry. 1997;170:205-28.

25. American Psychiatric Association. Diretrizes para o tratamento de transtornos psiquiátricos - Compêndio 2006. Porto Alegre: Artmed; 2006.

26. Nordstrom P, Samuelsson M, Asberg M. Survival analysis of suicide risk after attempted suicide. Acta Psychiatr Scand. 1995;91:336-40.

27. Pirkola SP, Isometsa ET, Heikkinen ME, Lonngvist JK. Suicide of alcohol misusers and non-misusers in a nationwide population. Alcohol. 2000;35:70-5.

\section{Correspondence:}

Maria Cláudia da Cruz Pires

Programa de Pós-Graduação em Neuropsiquiatria e Ciências do

Comportamento / Universidade Federal de Pernambuco

Rua das Pernambucanas, 282/305, Graças

52011-10 - Recife, PE - Brazil

E-mail: claudiacpires@globo.com 